\title{
The Effect of Internal, Industry and Macroeconomic Factors on Banking Profitability: Evidence from the Post 2000 Southern European Banking Sector
}

\author{
Nikolaos K. Kalogeridis ${ }^{1}$, Evagelos Drimbetas ${ }^{2}$, Marios E. Menexiadis ${ }^{3}$
}

\begin{abstract}
:
This paper examines the effect of bank, industry and macroeconomic determinants, on Southern Europe's universal bank profitability, during the period 2000 - 2013. Cross sectional panel data analysis is used.

The results show that the measure of capital adequacy and quality of assets (internal factors) has a significant impact on bank profitability. Moreover, the effect of industry factor measured by the H.H.I. (Herfindahl index), is quite significant and has a positive impact. Additionally, in the field of macroeconomic determinants, the measure of interest rate and the measure of economic growth (macroeconomic variables) are proven statistically significant with a negative effect.
\end{abstract}

Furthermore, the causality between the dependent and independent variables is examined (only for statistically significant co dependencies).

The originality of this study is that, for the first time in the literature, the GDP growth rate, for the time $t-1$ is considered as a proxy for the macroeconomic development. The variable of $G D P$ growth for the t-1 time is used as a precursor variable of economic growth.

Though there is plenty of bibliography regarding the relationship between GDP growth proxy and profitability ratio, the results of the studies contradict each other. These inconclusive results proved there is ground for further investigation and led us to the initiative of the present study.

Keywords: Banks, Performance, Profitability, Southern Europe.

\footnotetext{
${ }^{1}$ Technological Education Institute of West Macedonia, Department of Accounting and Finance, School of Management and Economics, nkalogeridis@gmail.com

${ }^{2}$ Democritus University of Thrace, Department of Economics, v.drimpetas@gmail.com

${ }^{3}$ National and Kapodistrian University of Athens, Department of Economics, mmenexiadis@ hotmail.com
} 


\section{Introduction}

The intense financial crisis of 2008 and its effects on the global economic environment sparked interest, at a scientific level, on the discovery and analysis of the factors that led to this deep crisis. It has also raised interest in the behavior of some key variables, such as banking profitability in the pre- and post-crisis period. The global financial system suffered from significant shocks. For a significant period, the lack of trust and the uncertainty that it created, brought asphyxia in the global financial activity.

This study focuses its attention on one of the most fundamental factor that assists in the smooth and unobstructed operation of the financial system, profitability. Business profitability in general as an essential determinant of investment, reinforces private consumption and contributes to the creation of a positive economic atmosphere thus supporting / amplifying the greater good of the economy and in turn, is supported by the healthy macroeconomic environment.

This interaction helps us to understand the importance of the healthy operation of banks, which is the most significant pillar of the global financial system. Especially for the banking sector, profitability above all else, constitutes a fundamental factor of "trust" in the robustness and solvency of the system. This element is considered as necessary for its flawless operation.

The time which this study focuses on is that of 2000-2013. The year selected as a starting point, signifies the introduction of the euro and thus the creation of the Monetary Union. The intense expansion of the financial activity, possibly via the ability to raise large amounts of capital at very low cost and the intense competition that banking organizations were facing in a growing market framework, are some of the characteristics that appear during this period. The year 2008, which signifies the start of the world banking crisis, transforms the general framework and places the system in a prolonged period of insecurity and uncertainty.

In addition, this study focuses on the countries of Southern Europe and more specifically on Portugal, Italy, Greece and Spain. These countries were the first to suffer the consequences of the global financial crisis of 2008 and are still affected till now. The basic objective of our study is to discover which of the fundamental factors affect the profitability of banking systems of Southern Europe for the period mentioned above and in which way. The additional material of this study is organized as follows:

1. Literature review,

2. Methodology and econometric results,

3. Conclusions.

\section{Literature Review}




\subsection{Banking sector and profitability}

Within the banking literature framework, most studies have selected as a dependent variable (rate of profitability) one of the following:

1) R.O.A or return on assets

2) R.O.E or return on equity

3) N.I.M Net Interest Margin

On the other hand, most of studies place the determining factors (independent variables) into three basic categories:

\section{- Bank specific determinants}

Factors that correlate with the function of the business itself and express to great extent, the managerial effectiveness in several fields of business activity. These are also known as internal factors. Studies examining internal factors that affect profitability, utilize numerous variables to express them, such as the size of business activity, capital adequacy, risk management, expense management, liquidity of the business units in the context of their operation etc.

The size of the business unit has a positive and statistically significant effect as documented by the studies of (Short, 1979; Bourke,1989; Molyneux and Thornton, 1992). Furthermore, the level of capital adequacy, which in most of studies is expressed with the equity to assets ratio, shows a positive and statistically important relationship with profitability. A bank with strong capital positioning can exploit with greater effectiveness its business opportunities and possesses more time and maneuverability, in order to deal with increasing unexpected loses. The avoidance of such unpleasant situations leads to profit increase (Athanasoglou et al., 2005). Opposite results, in relation to capital adequacy, have been expressed in the study of (Alexiou and Voyazas, 2009).

Molyneux and Thorhton (1992) have found a negative and substantial relationship between levels of liquidity and profitability. This conclusion is considered by the authors as logical because of high levels of liquidity that are correlated to low risk investments and subsequently low return investments.

On the contrary, Eichengreen and Gibson (2001), support the positive and statistically substantial relationship between liquidity and profitability, due to the potentiality to exploit opportunities on the market.

Miller and Noulas (1997) express the negative effect of financial risk on profitability. High-risk funding (high-risk loans) lead to higher levels of loan losses provisions and thus to low levels of profitability.

Athanasoglou et al. (2005) conclude that low quality assets in combination with low levels of liquidity lead to banking failures. In their study, in addition to the 
categorization of variables into internal, industry and macroeconomic, they also include the profitability variable of the previous year.

The relationship between the reason expressing the effectiveness of management in operating expenses (operating expenses to operating income ratio) and the measure of profitability is considered as negative in the studies of (Kosmidou et al., 2005; Capraru and Jhnatov, 2015; Athanasoglou et al., 2005; Liapis et al., 2013).

\section{- Industry specific determinants}

In the majority of studies, the effect of the sector is expressed by the variables of the $\mathrm{H}$. H. Index (Herfindahl Index), as well as the percentage of the overall sector held by the three or five largest banks at an assets level (CR-3, CR-5). The Market Power Hypothesis is included in the industry framework and recognizes that, only banking institutions with large market share and well diversified products, are in position to apply their leadership influence in order to increase their monopoly / oligopoly profits (non-competitive products) (Berger, 1995; Kosmidou, 2008; Athanasoglou et al., 2005; Samy Ben Naceur, 2003; Capraru, 2015; Hoffmann, 2011; Petria et al., 2013; Liapis and Thalassinos, 2013).

\section{- Macroeconomic determinants}

A large segment of international literature uses variables such as inflation, interest rates, market capitalization to G.D.P ratio, growth of G.D.P etc.

Revell (1979) introduces the issue of the relationship between the profitability of banking schemas and the level of inflation. He notes that the effect of inflation on bank profitability, depends on whether banking salaries and other operation costs increase at a faster percentage than inflation. Consequently, future inflation must be forecasted with precision, for managers of banking schemas to manage operation costs effectively. Perry (1992) states that the rate with which inflation affects bank profitability is reliant on the prediction of the real inflation rate, which provides the opportunity to managers of banking organizations, to adjust interest rates accordingly, to increase their profits at a faster rate compared to their costs, thus achieving greater financial gains. The positive and statistically significant effects of inflation point out the effectiveness of managerial forecasting at the level of inflation that leads to the correct handling of interest rates and the increase of banking profits. (Athanasoglou et al., 2005; Thalassinos et al., 2013; Thalassinos, 2008).

The relationship that takes shape between the overall performance of the assets to the interest of the 10-year yield bond, are negative and statistically significant. The level of bond performance determines to a great degree the level of creditworthiness of the country that issues them. The reduction of creditworthiness is accompanied by an increase in the general level of interest rates. The opposite occurs in the case of high creditworthiness. The level of creditworthiness of the country defines the systemic danger that companies, which are active in the interior of the country, face. Increased systemic danger is accompanied by increased loan interest rates._It can be 
easily inferred that the above process, has negative effects on the profitability of individual business formations active in the interior of the county.

Furthermore, high bond interest rates drive investors to differentiate their investment position, thus possibly repositioning their interests in long term government bonds. This move reduces the deposit base of banking institutions and forces them to increase both short and long-term deposit interest rates, to re-attract capital. This action increases the daily operation costs and negatively affects their profitability according to our opinion. The variable of stock market capitalization to G.D.P. constitutes a measure of financial growth and of the size of the financial market, with respect to overall size of the production activity of the country.

The stock market constitutes the market from which the banking system and other business ventures raise funds, to implement their investment plans. In addition, it measures the ability of the stock market to distribute capital to investment plans and the ability to provide important opportunities for diversification of risk for the investors (these include banking organizations). The well-developed capital markets are expected to reinforce the performance of banks. Banks can exchange shares into funds to use them in their day-to-day operations. More capital funds can be converted into higher profit for clients and shareholders (Berger, 1995).

The use of G.D.P growth as a variable isn't widely present in bibliography. The expected relationship is indicated by a positive sign, as higher development equals lower possibility of personal and business default as well as easier access to credit. The increase in GDP growth influences many factors that are correlated with supply and demand for loans and deposits. It is expected that bank profitability will be driven by the real G.D.P. (Kosmidou, 2008; Naceur, 2003; Abreu-Mendes, 2001; Havrylchyk and Jurzyk, 2006).

However, the coefficient can be negative, as countries with higher G.D.P theoretically possess a banking system that functions in a mature environment, resulting in more intense competitive surroundings and thus lower margins for profit. (Goldberg and Rai, 1996). The intense competitive environment forces management to constantly reduce profit margins, to cope with and sustain their market share. Thus, while the level of G.D.P. rises, the rate of profitability may fall. There is no limitation to the absolute size of profit, but only to the performance of assets. Both industry and macroeconomic factors are known as external factors.

\section{Methodological Approach and Econometric Results}

\subsection{Data}

This study utilizes data which have been drawn from the yearly economic reports of the four largest banks of countries in Southern Europe. In all cases, the four major banks cover a majority percentage of the banking sector. More specifically, there has 
been use of the S\&P Capital IQ data base and the DataStream data base. This study analyzes the time between 2000 and 2013.

\subsection{The model}

The general model that must be assessed has the following linear form:

$\Pi_{\mathrm{it}}=\mathrm{c}+\sum_{\mathrm{k}=1}^{\mathrm{K}} \beta \mathrm{kX} X_{\mathrm{it}}^{\mathrm{k}}+\varepsilon_{\mathrm{it}}(1)$

Where

$\Pi_{\text {it }}$ : profitability of bank $\mathrm{i}$ in time $\mathrm{t}$, with $\mathrm{i}=1,2, \ldots, \mathrm{N}$ and $\mathrm{t}=1,2, \ldots, \mathrm{T}$, c: fixed term,

$\mathrm{X}_{\mathrm{it}}^{\mathrm{k}}$ : $\mathrm{k}$ Interpretative variables,

$\varepsilon_{\mathrm{it}}$ : disturbance,

The Interpretative variables $X_{\text {it }}$ are grouped into internal, industry and macroeconomic variables. Thus the above equation takes on the form:

$\Pi_{i t}=c+\sum_{j=1}^{J} \beta j X_{i t}^{j}+\sum_{l=1}^{L} \beta l X_{i t}^{1}+\sum_{f=1}^{F} \beta f X_{i t}^{f}+\varepsilon_{i t}(2)$

Where

$\mathrm{X}_{\mathrm{it}}^{\mathrm{s}}$ describes the $\mathrm{j}, \mathrm{l}$ and $\mathrm{f}$ factors. These refer to the internal, external - industry and macroeconomic defining factors of profitability.

The original approach that is introduced by this study is the use of the G.D.P. variance of the previous year, as a macroeconomic factor that affects profitability. Thus, our intention is to investigate how the changing of G.D.P. levels of the previous year can constitute a precursor variable that alters bank profitability in the current time period.

\subsection{Studied factors}

Profitability is studied via the measure of total performance (R.O.A.). This coefficient is considered in our model as a dependent variable. As mentioned above, the independent variables that affect profitability are separated into three basic groups: the group of internal factors, that are affected by the operation of the business itself, the group of industry factors and the group of macroeconomic factors as external factors, which affect profitability of the studied banking institutions.

The internal factors analyzed in this study are four:

1. Capital;

2. Loans Portfolio Quality;

3. Performance;

4. Liquidity.

Capital: In this study, as measure of capital calculation we utilize the ratio of Equity to Total Assets. This relationship is expected to be positive. The merit referring to capital is the merit that can support various business activities of the studied business and can constitute a safe funding network, even during periods of unfavorable 
development. The ability of unobstructed continuation of business activity is what is expected to increase the level of profitability and provide a significant comparative advantage against the competition. This variable is represented by the symbol CAP.

Loans Portfolio quality: To calculate the variable of loans portfolio quality, we use the ratio of Loan Losses Provisions to Total Loans. The increase on Loan Losses Provisions, is expected to have a negative relationship to the calculation measure of profitability. The provisions for bad loans entail the reduction of profitability levels. In this section, we mention that Central banks define specific conditions for the provisions levels of bad loans that must be adopted by banks of their own countries. Bank management pre-calculates their provisions at the start of the year, attempting to monitor and - in numerous cases - to affect the index course in their favor. In other words, the course of this index shows the quality of business management in matters relevant to loan losses provisions. This variable is named QUALITY.

Performance: This variable result from the operational expenses to operational income ratio. It is expected to have negative results. This means that increased operational expenses decrease the level of profitability. However, there are cases where this relationship is positive, and this reflects the increased productivity of the employees, when they receive additional motivation for their labor. This variable is represented by the symbol EFFIC.

Liquidity: Liquidity is calculated by the current assets to the total assets ratio. In other words, it expresses the participation percentage of the directly liquefiable assets in relation to the total assets. The relationship of this variable with profitability is expected to be positive. Increased current assets equal more opportunities for the achievement of better performance (due to increased liquidity). In addition, it expresses management quality in the decision-making process. This variable is symbolized by LIQUID.

It must be pointed out that, due to its accounting nature, this relationship could have negative results, explaining management inadequacy in the decision-making process and the diminished efficiency of management in general.

In our study we use as an external - industry factor the Herfindahl index (for assets). As previously mentioned, this index, also known as the HerfindahlHirschman (H.H.I. abbreviated), is a measure of calculation of industry accumulation. The index holds values from 0 to 10.000 . Holding the value 10.000 signifies that the market is owned by one monopolist, while holding a value of 0 signifies that the market is owned by a large amount of businesses that control a very small share of the market. The relationship that is created between this industry factor and the factor of profitability usually has a positive result. The power possessed by businesses that are active in an industry with high concentration percentages allows them to impose, due to their size, the terms that they desire and consequently to increase their profitability. The relationship can also be expressed as 
negative and suggests the appearance of anti-economies of scale and phenomena of heavy bureaucratic structure, that inhibit the optimization process of the results of profitability. At the level of external - macroeconomic variables we use the following variables:

- Inflation;

- 10-year bond interest rates;

- Gross Fixed Capital Formation;

- Stock market capitalization index to Gross Domestic Product;

- Gross Domestic Product percentage variation of the previous year.

Inflation: As we can see, inflation constitutes a basic element of an economy that intensely affects its daily operation. The reduction of buying power, which is implied by this index, leads to the reduction of private and public consumption and thus may have a negative effect in the growth rates of the economic activity.

Moreover, inflation may result in a management weakness to respond and predict on time to the variance in the general level of prices by adjusting their options accordingly to contain-eliminate or even, reverse this relationship form negative to positive. This relationship is expected as negative in relation to the general level of profitability. In our study, this is represented by the symbol INFLATION_RATE.

10-years bond interest rates: As mentioned above, the 10 years bond interest rate affect the general level of interest rates. From this prospect, the level of interest rates that the state must pay to derive funds, affects its subsequent development. In addition, it affects, via its diffusion in the real economy, the shaping of profitability for business units that operate within the country. This relationship is expected to have negative results and shows us that increased cost encumbrance in the process of drawing funds, from the state, equals to limited levels of profitability (via the diffusion of the results of the first). The symbolism used in our study for this variable is INTEREST_RATE.

Gross Fixed Capital Formation: This refers to the sum of expenses for agricultural and metal products, machinery, transportation equipment, housing development, other construction and changes in reserves that the private sector creates. With this factor we calculate the participation of the private sector in the total of investments. Fixed capital investments are the foundation of the growth process of a country's G.D.P. and it also affects the demand for loans from the banking sector. The weakening low rates of Gross Fixed Capital Formation equals low or even stagnant G.D.P. growth. It reflects the poor expansion of the production capabilities of the economy, political, economic and social destabilization etc.

This relationship is expected to be positive. The continuous rising trend of this factor helps internal business activity, thus improving the conditions of profitability for individual business units. This variable is symbolized as INVEST. 
Stock Market Capitalization Index to Gross Domestic Product: The stock exchange market constitutes a market for both short and long term raise of capital for the various business schemas operating within an organized state. This capital is utilized for the implementation of various business plans and increases business efficiency, as well as the production capability of the country where such activity takes place. The ratio reflects the size of the secondary market in relation to the production ability of the country of origin.

The increased volume of a secondary market in relation to the country's production ability equals increased opportunities for funding, but simultaneously increased levels of risk in a potential stock market crisis. It also suggests the weakness of selfre-supply of business activity from the already committed business activities and the constant need for external funding.

The immediate consequence of the above is increased risk levels, which are related to the various changes of the external business environment. This relationship is expected to be positive without excluding the possibility of its negative expression. The symbol for this variable is MARKETCAP_TO_GDP.

Percentage variance in last year's Gross Domestic Product: Percentage variance in G.D.P. of the previous year is used for the first time (according to our search) and is expected to show its proactive effect on the profitability of the individual business groups operating within the reference country. This relationship is expected to be positive without excluding the possibility of its negative expression. In the first case, it suggests a smooth diffusion in the operation growth of individual business groups, while in the second it suggests the inability of management to denote the increased activity in asset options with increased returns. It is represented with the GDPGRBE symbol.

\subsection{Econometric methodology}

The data used in this study has been drawn from the annual financial reports of the four largest banks of each country of Southern Europe. Cr-4 represent the largest part of the banking market in the countries of Southern Europe. The data were collected by utilizing the S\&P Capital IQ data base. The macroeconomic and industry data has been derived from the World Bank and E.C.B. (European Central Bank) data bases respectively. The program selected for conducting the econometric study is e-views. The data refer to the chronological period of 2000-2013 and includes a large portion of balance sheet and operating income results. In the study we use the method of ordinary least squares O.L.S. to calculate the parameters of regression with cross section and time series data (Panel data). The following checks are adopted to control linear constraints:

- control of the stationarity of the time series used;

- control of multicollinearity; 
- control of the constant fluctuation assumption (homoskedasticity of the model);

- control of the cointegration;

- control of zero covariance (absence of autocorrelation).

The possible problems that arise in relation to the existence of heteroskedasticity and cross-sectional dependences are solved by using the P.C.S.E. model (Panel Corrected Standard Errors Model).

\subsection{Econometric results}

Stationary time series:

- CAP; EFFIC; GDPGRBE; INFLATION_RATE; INTEREST_RATE; INVEST; MARKETCAP_TO_GDP

Stationary in the $1^{\text {st }}$ level:

- CRED; HERFINDAHL; LIQUID; ROA

Due to the use of the first differences (to solve the problem of some time series stagnation), the time series used in our regression are limited to the period of 20002013. In the context of the study of multicollinearity testing through the increased fluctuation factor VIF, we have the following results:

$\mathrm{VIF}=1 / 1-\mathrm{R}^{2}=1 / 1-0.662489=1 / 0.337511=2.962866<5$

The level of the increased fluctuation factor VIF is less than the initial peak we have set in this study. The value of 2.962866 indicates the absence of multicollinearity. The model supported in this dissertation has an interpretative capacity of $66.24 \%$. In other words, the relationship studied is interpreted in this percentage by the existing variables. The remaining percentage refers to variables not included in the model. The selection between the appropriate Random or Fixed Effect models is done using the Hausman test. The Hausman test indicates the suitability of the Random Effect Model (prob 1,000).

The heteroskedasticity and cross-sectional dependencies problems that occur in our time series, are solved by utilizing the Panel Corrected Standard Error Model (P.C.S.E.) method. Next, by using the P.C.S.E. model we receive the following results regarding our regression which can be summarized as follows:

- The dependent variable R.O.A. is linked in a positive and statistically significant way to the following variable:

- HERFINDAHL (+) (external industry variable)

- The dependent variable R.O.A. is linked in a negative and statistically significant way to the following variables:

○ CAP (-) (internal variable) 
- CRED (-) (internal variable)

- GDPGRBE (-) (external macroeconomic variable)

- INTEREST_RATE (-) (external macroeconomic variable)

- The dependent variable R.O.A. is linked in a positive and non-statistically significant way to the following variables:

- INFLATION_RATE $(+)$ (external macroeconomic variable)

- INVEST (+) (external macroeconomic variable)

- The dependent variable R.O.A. is linked in a negative and non-statistically significant way to the following variables:

- EFFIC (-) (internal variable)

- LIQUID (-) (internal variable)

○ MARKETCAP_TO_GDP (-) (external macroeconomic variable)

In the context of the econometric study, the short-term equilibrium was also sought out by using the Granger causality test. Through this, causality is found between statistically significant relationships (as reflected by the effects of regression). This relationship can be unidirectional (one-way) or bidirectional (two-way). The results of the Granger Causality Test are as follows:

The relationship that is formed between the level of the 10-year bond yields (INTEREST_RATE) and asset efficiency (R.O.A.) can be described as bidirectional. The probabilities of both paths are lower than the level of significance we have set $(\alpha=0.05)$. Therefore, we reject the null hypothesis referring to the lack of causality and adopt the alternative hypothesis that states the existence of causality. By interpretation, we could argue that rising levels of profitability lead to a reduction in the level of ten-year bond yields (a satisfactory performance of the banking industry's assets sheds positive light on the operation of an economy, resulting directly in further reductions of interest rates due to a higher credit rating of the economy). The reduction of interest rates in turn supplies the growth of the profitability component.

Respectively, the relationship shaped between the asset performance variable (R.O.A.) and the level of industry concentration (HERFINDAHL) can be described as unidirectional and is derived from the asset performance variable to the variable measuring the level of concentration. The probability in this path is lower than the level of significance we set $(\alpha=0.05)$, which leads us to reject the zero hypothesis and to adopt the alternative. Increased profitability levels strengthen industry concentration. Thus, it can be deduced that the rising efficiency on assets for the CR4 of the European South, helps to reinforce their position in the industry and inductively enhances the level of industry concentration.

The relationship of R.O.A. and gross domestic product variance of the previous year appears as one-dimensional and moves from the macroeconomic factor to the asset efficiency factor. The probability is significantly lower than the level of significance we have set. The null hypothesis is rejected and the alternative suggesting the above 
relationship is adopted. By interpretation, the causal relationship can be described as expected. The fact of the negativity of the functional relationship reflects the inability of the management (through their decisions) to efficiently transform the increase in the level of the country's productive activity to high efficiency assets. The relationship between the variable CAP and the variable R.O.A. shows two-way causality. The probabilities in both instances are below the level of significance that has been set. The zero hypotheses are discarded to adopt their alternatives.

\section{Empirical Findings}

The relationship formed between the independent R.O.A. variable, which measures the performance of assets in total and reflects the ability of bank management to generate profits from assets, and the EQ/AS variable, which measures capital adequacy, appears, negative and statistically significant. The increase in participation of equity in total assets leads to a reduction in the participation of profits in total assets. In other words, the additional equities are transformed into assets, whose performance is disproportionate. The path created leads to a higher percentage variance in assets, in relation to the fluctuation of absolute profit size. In other words, more than necessary funds are raised, leading to investments with diminished marginal return and to decrease in average effectiveness of assets.

A plausible interpretation of this may be that it is due to the inability of management in the banking systems of southern Europe to invest the funds raised in such a way that increases the measure of profitability and creates sources that supply daily operation, thus reducing dependency on equity. Equities are elements utilized for financing the activities of each business. They are elements that include costs and are converted through the management option into revenue-generating assets.

In the case of banking organizations, most of the assets consist of loans (consumer, housing and business) and investments in investment products. Their performance depends on both the spread and the risk incurred by the positioning. High-risk positions may yield high returns in the short term, however in the medium to long term, they reduce the level of profitability. High-risk positions require higher levels of provisions for bad debts (even higher in financial crisis situations), which in turn impose an additional inflow of equities to cover the "opening" created. This process is intensified during situations of severe financial shock (global financial crisis 2008).

This feedback creates important dependencies on the day-to-day operation of banking schemas. It may impose aggressive dividend policies (which will facilitate the attraction of funds), increasing however the cost burden, thus leading to investments of even greater risk in order to offset the situation. The above situation is compounded both by the policy of extra wages (productivity bonus), as motivation to increase productivity and by the aggressive investment rationality of the stakeholders. 
Additionally, the increased ability to raise capital at the beginning of the review period does not equal substantial investment opportunities. This possibly implies that greater funds were drawn, than those that could be absorbed in an effective way. In the case we are studying, the feedback relationship is also proven by the causal relationship between the two variables. Through the Granger causality test we find their bidirectional relationship.

Both Tregenna (2009) and Hoffmann (2011) have agreed with the findings of our study. About the relationship between the liquidity variable (Liquid Assets/Total Assets) and the total return on assets (R.O.A.), it is negative and close to the limit of statistical significance (for $\alpha=0,1$ ). This indicates that, as the level of liquid assets increases in relation to total assets (Liquid Assets/Total Assets), the level of profitability is negatively affected. In other words, increased liquidity cannot lead to opportunities - positions that proportionally increase the measure of total return on assets (R.O.A.).

Insufficient liquidity is one of the main reasons for the failure of banking organizations. However, the possession of assets in an instantly liquid form implies significant opportunity costs for higher returns. Bourke, in a 1989 study, notes the positive and statistically significant relationship between liquidity and profitability for the banking industry.

However, in times of economic instability, maintaining high levels of liquidity is necessary to mitigate and address threatening risks. During these times, the relationship between the measure of liquidity and that of profitability is negative. Molyneux and Thorton in their 1992 study agree with this claim.

The Southern Europe banking system sacrifices opportunities for increased return on assets by choosing to place funds in low-yielding assets, to be able to respond to the scenario of severe financial crisis, such as 2009 crisis. The situation described is in line with the Risk-Return Hypothesis.

As we have already mentioned, in agreement with the results of the study in this particular filed are Molyneux and Thorton (1992), Alexiou-Voyazas (2009), Capraru-Jhnatov (2015) as well as Davydenko (2011). In the case of the study of Alexiou and Voyazas, (2009) the measure of liquidity is reflected by the ratio of loans to total deposits (Loans / Deposits).

The relationship between the variable that measures the quality of the loan portfolio (L.L.P. / Total Loans) and the dependent variable R.O.A. is given a negative value and has a high statistical significance. This means that as the quality of the loan portfolio deteriorates, the provisions for bad loans in the entire loan portfolio increases. The ratio of provisions to total loans (L.L.P./TL.) increases when the growth rate of provisions is higher than the growth rate of loans. Provisions for bad loans limit the absolute size of profit and thus the measure of total return on assets. 
In addition, this may also mean that the growth limitation of the new loans market can reduce the ability of banking schemas to increase their lending activity to a higher level than Loan Losses Provisions. The quality of the loan portfolio is largely dependent on exogenous shocks, particularly in financial crisis situations, such as that of 2009. The growth rates reduction in the production ability of the country, from which the banking schema originates, has an inductive effect and limits the ability to meet contractual day-to-day obligations both by entrepreneurs and households in general. Failure to comply with the terms of the loan agreements leads to an increase in provisions and a decrease in the level of profitability.

In agreement with the findings of our study are (Alexiou and Voyazas, 2009; Kosmidou, 2008; Staikouras and Wood, 2011; Athanasoglou et al., 2005; Gong Cheng and Dirk Mevis, 2015; Capraru and Jhnatov, 2015; Alpre and Andar, 2011; Davydenko, 2011; Hassan and Bashir, 2003). In the case of the last two studies, the relationship is negative but statistically insignificant.

The efficiency index (operational expenses/operational income) is related to the total return on assets ratio R.O.A., in a negative but not statistically significant way. This negative relationship suggests that rising operating costs relative to operating income have contributed to lower levels of profitability. It could be stated that the increased costs were allocated in such a way as to contribute to the limitation of asset profitability. Expenses at the operational level, can often also be an incentive for increased productivity. This increased productivity may conditionally lead to a reduction in marginal costs and, in turn, to an increase in profitability.

In agreement with the results of our study are Athanasoglou et al. (2005), Kosmidou et al., (2005), Alexiou and Voyazas, (2009), Tregenna (2009), Davydenko, (2010) and Capraru and Jhnatov (2015). Within the industry variables and in relation to industry concentration, as already mentioned, the Herfindahl-Hirschman index (abbreviated H.H.I.) is used.

The relationship of this indicator with the overall asset efficiency measure, as shown by the results of the econometric study, is positive and statistically significant. The findings are in line with the Market-Power Hypothesis, which implies that the higher the level of concentration (and therefore the market share held by market-based organizations), the higher the level of profitability they achieve. Higher market concentration equals higher shareholdings for a small number of banks. This concentration allows larger banking schemas to impose their policy on the market and achieve higher levels of profitability.

In addition, the concentration of the industry in a smaller number of banking institutions leads to oligopolistic logic and strategies, which results in a significantly higher pricing policy and creates significant obstacles for market entry. 
Furthermore, the size of banking institutions greatly increases the possibilities for exploiting investment opportunities. The causality relationship between the two variables examined appears to be one-dimensional (unidirectional). The results of the Granger causality test show causality that starts with the profitability measure of R.O.A. and is driven towards the Herfindahl industry concentration variable. According to (Berger, 1995), management efficiency not only increases profits, but can also lead to market share gains and increased market concentration.

The findings of the study on this relationship are in line with the results of the studies of Trujillo- Ponce (2013), Alexiou and Voyazas (2009), Staikouras and Wood (2011), Kosmidou et al. (2012), Davydenko (2010), Tregenna (2009), Bourke (1989), Molyneux and Thornton (1992) and Havrylchyk and Jurzyk (2006).

In the context of the macroeconomic variables that influence the formation of the profitability measure R.O.A. we have selected, as already mentioned, the inflation index (inflation rate), the ten-year rate index (interest rate), the gross fixed capital formation index (invest), the stock market capitalization index to GDP and the GDP variance indicator of the previous year (G.D.P. growth before).

The relationship between inflation (inflation rate) and total return on assets (R.O.A.) is positive and statistically insignificant and reflects the manager's ability to raise product prices faster than inflation, to increase the profits. Inflationary pressures in an economy tend to force change in the overall policy of various business schemas in the pricing of their products. This change in turn leads to further increases in the consumer price index.

This vicious circle makes it difficult to undertake investment opportunities and, in the medium to long term, leads to destabilizing trends in economic activity overall. The results of our study are consistent with those of Alexiou and Voyazas (2009), Gong Cheng and Dirk Mevis (2015), Alpre and Andar (2011), Davydenko (2010), Hammed and Bashir (2003) and Molyneux and Thornton (1992).

In our study, as mentioned, we adopt - as an interest rate index - the interest rate of 10 -year bonds. The relationship between the overall performance on assets and the ten-year bond rate is negative and statistically significant. The level of bond performance determines to a significant degree the level of credit rating of the issuing country. Low credit worthiness is accompanied by increased interest rates. The opposite is true in the case of a high credit standing. The level of the country's credit worthiness also determines to a significant extent the systematic risk faced by businesses operating within its borders. Increased systematic risk is accompanied by an increased borrowing rate.

It can be deduced that the above process negatively affects the profitability of individual business entities operating within the country. The rise in the interest rate level of government bonds (if not predicted in time and transferred to the client base) is followed by a decline in the overall profitability of bank institution assets. Also, 
high levels of bond rates drive investors to change their investment strategy and position themselves in government bonds of possibly long duration. This move reduces the deposit base of banking institutions and forces them to increase both short and long-term deposit rates in order to re-attract capital. This action increases their daily operational costs and negatively affects the level of profitability.

The ability to compensate for the above situation is provided through the placement of excess liquidity in bond securities. However, this placement increases the level of interconnection between banking and government operations and exposes the system to greater risks. A typical example is that of the Greek economy, which restructured its debt through the "haircut" process of part of the bonds it had issued (P.S.I., March 2012). The bonds held by the Greek banks lost a significant portion of their nominal value and led to their need for recapitalization. The findings of our study agree with those of Trujillo and Ponce (2013).

The causal relationship between the two variables examined appears to be bidirectional. The results of the Granger causality test show causality which feedbacks between the 10-year government bond yield and the profitability measure R.O.A. This feedback significantly increases the potential of macroeconomic and financial crises. The relationship between the investment index (which in our study is gross fixed capital formation) and the overall return on assets is shown as positive, but not statistically significant.

Gross fixed capital formation constitutes the sum of the expenditure on agricultural and metal products, machinery, transport equipment, housing construction, other construction and inventory changes made by the private sector. This factor calculates the private sector's contribution to total investment. Its evolution over time demonstrates the impact of investment initiatives on the development process. Fixed capital investments form the foundation of the GDP growth process of the country.

The weakening of gross fixed capital formation implies low to stagnated GDP growth. It reflects the minimal utilization of the productive potential of the economy, political, economic and social destabilization, etc. The constantly rising trend of this factor assists internal business and thus improves the terms of profitability of individual business units. The results of our study are in line with the theoretical approach. In the context of investigating the relationship between the stock market capitalization index to G.D.P. (Market capitalization/G.D.P.) and the total performance on assets, we note the negative but not statistically significant relationship.

The variable of stock market capitalization to G.D.P. is a measure of financial growth and the size of the financial market, in terms of the total breadth of the country's production capacity. The stock market is the space via which both the banking system and other business initiatives raise funds to implement investment projects. It measures the ability of the stock market to allocate funds to investment 
plans and its ability to provide significant opportunities for diversifying risk to investors (including banking institutions).

Well-developed capital markets are expected to enhance bank performance. Banks can exchange shares and increase their capital requirements. Most funds can translate into higher profits for customers and shareholders (Berger, 1995). In addition, stock markets provide banks with liquidity and opportunities to diversify their portfolios (Demirguc-Kunt and Maksimovic, 1996).

However, the operation of the stock market, from a certain point on, could operate competitively against banking. Continuous reduction in the level of bank lending and its substitution with funds drawn from the stock market limits their level of activity and reduces their profitability. The results of the study are consistent with those of Kosmidou (2008), Hammed and Bashir (2003).

In the study contacted by Kosmidou (2008), the measure of capital market development is the ratio of capitalization of the stock exchange to the total assets of bank depositories. The relationship between the financial growth variable of the previous year and the asset efficiency measure is positive and statistically significant. The original nature of this study is that it introduces for the first time this precursor growth index. The increase in the production capacity of the economy is part of the overall economy with some delay. For this reason, in the study we use the GDP variance at $\mathrm{t}-1$ as an index of growth. The fact that this variable has not been used previously compels us to compare our results with studies that integrate in their search parameters the growth of economic activity of the current period.

The intense competitive environment forces management to continuously reduce profit margins to be able to cope and maintain their market share. Thus, while the level of GDP increases, the profitability rate decreases. There is no limitation on the absolute size of profits, but there is on the performance of the assets. In other words, the new positions in assets do not have correspondingly similar performance to previous positions. The example of the Southern European banking system confirms this claim.

Our study, as we have already mentioned, indicates a negative correlation with high statistical significance and is consistent with the results of the studies of Staikouras and Wood (2011), Goldberg and Rai (1996), Alpre and Andar (2011), Claeys and Vennet (2003). The causal relationship between the two variables examined is a oneway (unidirectional) relationship. The results of the Granger causality test show causality influenced by the measure of G.D.P. growth of the previous time (G.D.P. growth t-1) to the measure of profitability R.O.A.

\section{Conclusions}


Over the last years, many published studies have searched for the factors that have an impact on the profitability of the banking sector, although having inconclusive results. Our research deals with the determinants of Southern Europe banking system profitability. The examined period is 2000-2013. The original approach introduced by this study is the use of the G.D.P. variance of the previous year, as a precursor macroeconomic variable that affects profitability. Furthermore, the Granger Causality test is used to calculate the sort- term equilibrium.

The results which are related to internal factors indicate that more than necessary funds were raised, leading to a decreased effectiveness of assets and to investments with diminished marginal return, creating needs for new equities. In other words, greater funds were drawn than those that could be absorbed effectively.

Additionally, the financial crisis of 2008 had a direct effect on banking profitability. The failure to comply with the terms of the loan agreements led to an increase in provisions and to a decrease in the level of profitability. The growth limitation of the new loans market also reduced the ability of banking schemas to increase their lending activity to a higher level than Loan Losses Provisions.

In relation to the industry factor, the findings of our study are in line with the Market- Power Hypothesis. The concentration of the industry in a small number of banking institutions led to oligopolistic strategies, resulting in a significantly higher pricing policy and creating significant obstacles for market entry. Management efficiency not only increased profits, but also led to market share gains and increased market concentration.

In relation to the macroeconomic factors, the results led us to conclude that higher levels of bond rates drove investors to change their investment strategy and position themselves in government bonds of possibly long duration. This move reduced the deposit base of banking institutions and forced them to increase both short and longterm deposit rates, to re-attract deposits. This action increased their daily operational costs and affected negatively the level of profitability.

In developed economies the intense competitive environment forced managers to continuously reduce profit margins, to maintain their market share. Thus, while the level of GDP of the previous year increased, the profitability rate decreased.

\section{References}

Alexiou, C. and Voyazas, S. 2009. Determinants of bank profitability: Evidence from the Greek banking sector. In: Ekonomski anali 54(182), 93-118.

Alper, D. and Anbar, A. 2011. Bank specific and macroeconomic determinants of commercial bank profitability: empirical evidence from Turkey. Business, Economics Research Journal 2(2), 139-152. 
Athanasoglou, P. Brissimis P. and Delis, S.N. 2005. Bank-Specific, Industry-Specific and Macroeconomic Determinants of Bank Profitability. Bank of Greece. Working Paper No. 25.

Bashir, A., Hammed, M. 2003. Determinants of profitability in Islamic banks: Some evidence from the Middle East. Islamic Economic Studies, 11(1), 31-57.

Berger, A.N. 1995. The profit-structure relationship in banking - tests of market-power and efficient-structure hypotheses. Journal of Money. Credit and Banking, 27(2), 404-431.

Bourke, P. 1989. Concentration and Other Determinants of Bank Profitability in Europe, North America and Australia. Journal of Banking and Finance, 13, 65- 79.

Capraru, J. 2015. Determinants of bank's Profitability in EU15. De Gruyetr open doi 10.1515/AICUE-2015-0007.

Gong, C. and Dirk, M. 2015. What happened to profitability? Shocks, challenges and perspectives for euro area banks. European Stability Mechanism. Working Paper Series 5.

Claeys, S. and Vennet, R.V. 2008. Determinants of bank interest margins in Central and Eastern Europe: A comparison with the West. Economic Systems, 197-216.

Davydenko, A. 2011. Determinants of Bank Profitability in Ukraine. Undergraduate Economic Review, 7(1).

Deger, A. and Adem, A. 2011. Bank Specific and Macroeconomic Determinants of Commercial Bank Profitability: Empirical Evidence from Turkey. Business and Economics Research Journal, 2(2), 139-152.

Demirguç-Kunt, A. and Maksimovic, V. 1998. Law, finance, and firm growth. The Journal of Finance, 53, 2107-2137.

Eichengreen, B. and Gibson, H.D. 2001. Greek banking at the dawn of the new millennium. CERP Discussion Paper 2791. London.

Goldberg, L.G. and Anoop, R. 1996. The structure-performance relationship for European banking. Journal of Banking \& Finance, 20(4), 745-771.

Hassan, M.K. Bashir, A. 2003. Determinants of Islamic Banking Profitability. Paper Presented at the Proceedings of the Economic Research Forum 10th Annual Conference. Marakesh-Morocco.

Havrylchyk, O. and Jurzyk, E. 2006. Profitability of foreign banks in Central and Eastern Europe: Does the entry mode matter? BOFIT Discussion Papers 5.

Hoffmann, P.S. 2011. Determinants of the Profitability of the US Banking Industry. International Journal of Business and Social Science, 2(22), 255-269.

Kosmidou, K. 2008. The Determinants of Banks' Profits in Greece during the Period of EU Financial Integration. Managerial Finance, 34, 146-159.

Kosmidou, K. Pasiouras, F. and Tsaklanganos, A. 2006. Domestic and multinational determinants of foreign bank profits: The case of Greek banks operating abroad. Journal of Multinational financial management, 17, 1-15.

Kosmidou, K. Tanna, S. and Pasiouras, F. 2012. Determinants of profitability of domestic UK commercial banks: Panel evidence from the period 1995-2002. 37th Annual Conference of the Money. Macro and Finance Research Group. held 1-3 Sept., Rethymno, Crete.

Liapis, K., Thalassinos, I.E. 2013. A Comparative Analysis for the Accounting Reporting of "Employee Benefits" between IFRS and other Accounting Standards: A Case Study for the Biggest Listed Entities in Greece. International Journal of Economics and Business Administration, 1(1), 91-116. 
The Effect of Internal, Industry and Macroeconomic Factors on Banking Profitability: Evidence from the Post 2000 Southern European Banking Sector

92

Liapis, K., Rovolis, A., Galanos, C. and Thalassinos, I.E. 2013. The Clusters of Economic Similarities between EU Countries: A View Under Recent Financial and Debt Crisis. European Research Studies Journal, 16(1), 41-66.

Miller, S. and Noulas, A. 1997. Portfolio mix and large-bank profitability in the USA. Applied Economics, 29, 505-512.

Molyneux, P. and Thorton, J. 1992. Determinants of European Bank Profitability: A Note. Journal of Banking and Finance, 16, 1173-1178.

Perry, P. 1992. Do banks gain or lose from inflation. Journal of Retail Banking 14(2), 25-30.

Revell, J. 1979. Inflation and financial institutions. Financial Times, London.

Short, B. 1979. The Relationship between Commercial Bank Profit Rates and Banking Concentration in Canada, Western Europe and Japan. Journal of Banking and Finance, 3, 209-219.

Staikouras, C.K. and Wood, G.E. 2011. The Determinants of European Bank Profitability. International Business \& Economics Research Journal, 3(6), 57-68.

Thalassinos, I.E., Venediktova, B., Staneva-Petkova, D. 2013. Way of Banking Development Abroad: Branches or Subsidiaries. International Journal of Economics and Business Administration, 1(3), 69-78.

Thalassinos, I.E. 2008. Trends and Developments in the European Financial Sector. European Financial and Accounting Journal, 3(3), 44-61.

Tregenna, F. 2009. The fat years: the structure and Profitability of the US banking sector in the pre-crisis period. Cambridge Journal of Economics, 33, 609-632.

Trujillo-Ponce, A. 2013. What determines the profitability of banks? Evidence from Spain. Accounting and Finance, 53, 561-586. 